\title{
EFFECTS OF ACCIDENTAL ANTIHYPERGLYCEMIC OVERDOSES ON LYSOSOMAL ENZYMOLOGY IN PATIENTS WITH TYPE 2 DIABETES MELLITUS
}

\author{
BY \\ Sherif M. H. El-Kannishy, Azza A. El-Baiomy*, Ibrahim Abdel-Aal*, \\ Alaa M. Wafa** and Heba G. Kotb*** \\ Analytical Toxicology Unit, Mansoura University Emergency Hospital; Departments of Clinical Pathology* \\ and Internal Medicine**, Faculty of Medicine, Mansoura University and Forensic Medicine and \\ Clinical Toxicology, Faculty of Medicine, Cairo University****
}

\begin{abstract}
Background: Quantitative estimation of lysosomal enzymes in the blood reflect the pathophysiological state of the intracellular lysosomes and subsequently the mother cells. Aim: To assess the effect of induced hypoglycemia due to accidental intake of antihyperglycemic drugs (insulin and/or sulfonylurea) overdoses by type-2 diabetic patients on some serum lysosomal enzymes. These are reliable markers of the intracellular lysosomal bioactivities and long-term cell lifespan. Subjects and Methods: Thirty type-2 diabetic patients suffering from severe hypoglycemia because of accidental overdose intake of insulin injection (8 patients), sulfonylurea ingestion (10 cases) or both drugs together (12 patients) due to drug automation and/or missed or disproportionate meal. At the same time, 15 patients with controlled DM, 15 patients with uncontrolled DM and 10 healthy reference individuals were studied. All these groups were almost of matched age, sex and body weight. Blood samples were withdrawn after breakfast and the designated antihyper-glycemic intake. Beside, plasma glucose, three serum acidic lysosomal enzymes i.e. the carbohydrase: BN acetyl glucosaminidase (B-NAG), the protease: cathepsin-D (CATH-D) and the monophosphoric ester hydrolase: non-prostatic acid phosphatase (NPAP) were determined by the respective colorimetric method. Results: Accidental intake of insulin injection and/or oral antihyperglycemic drugs in overdoses induced significant increase of the estimated serum lysosomal enzymes. In this respect, the response to insulin was higher but shorter than that by sulfonylurea intoxication. At the same time, BNAG had higher response than CATH-D and NPAP to the antihyperglycemic drug overdoses. There was no significant correlation between plasma glucose concentrations and the estimated serum lysosomal enzyme activities in the different studied groups. The results of the controlled euglycemic diabetics were significantly lower than those in the hypoglycemic group but not significantly different from those in the healthy group. At the same time, the results of the uncontrolled diabetics were significantly lower than those in the hypoglycemic group but significantly higher than the respective values of the healthy refer-
\end{abstract}


ence group. Conclusion: Insulin overdose hypoglycemia in diabetic patients induced a significant increase in libation of the studied lysosomal enzymes (B-NAG, CATH-D and NPAP) more than by sulfonylurea toxicity. On the other hand hyperglycemia in uncontrolled diabetics induced significantly higher serum lysosomal enzymes than normal but significantly lower than those in hypoglycemics. Serum lysosomal enzymes profile is a mirror of the intracellular lysosomal biological state and consequently the cell life span.

Key Words: Bn Acetyl Glucosaminidase, Cathepsin-d, Non-prostatic Acid Phosphatase, Body Mass Index, Antihyperglycemics, Type 2 Diabetes Mellitus.

\section{INTRODUCTION}

Management of patients with type 2 diabetes mellitus usually involved combined pharmacological therapy to obtain adequate blood glucose control and treatment of concurrent pathologies particularly dyslipidemia and arterial hypertension. Antidiabetic medications include insulin compounds given parenterally and insulin secretagogues given orally. In management of type $2 \mathrm{DM}$, oral antihyperglycemics should be tried before insulin therapy is allowed (Scheen, 2005). Antihyperglycemic therapy aims to normalize the diabetic metabolic anomalies and subsequently prevents or reduces morbidity and mortality caused by the relatively common serious diabetic complications (Riley and Kastrup, 2001).

Hypoglycemia may occur if the antihyperglycemic therapy is more than really required, there is a missed meal after the intake of the recommended therapy or after unplanned physical or mental stress. Severe hypoglycemia may lead to death unless dextrose is promptly and adequately administered (Granner, 2000). Insulin self poisoning is rare. Its prognosis relies on clinical findings and time of initiation of management. About $16 \%$ of patients developed severe hypoglycemia, half of them died (Megarban et al., 2007).

Lysosomes are intracytoplasmic organelles that contain different acid hydrolases (optimum pH 4.0) which comprise lipases, carbohydrases, proteases and others. They are the intracellular garbage system that degrade the intracellular bacteria and worn out organelles. Lysosomes are frequently nicknamed "suicide-bags" or " suicide-sacs" due to their role in autolysis. Small cell amounts of lysosomal enzymes are normally released into the extracellular milieu. They are inactive at the normal blood $\mathrm{pH}$ (7.3-7.4). However, in some cases larger amounts are released into blood due to pathophysiological or genetically determined lysosomal disorders (Junqueira et al., 2005; Maehr et al., 2005; van Meel and Klumperman, 2008). 
Diabetic patients had higher concentrations of blood lysosomal enzymes e.g., BN acetyl glucosaminidase (B-NAG) (Agardh et al., 1991). The circulating lysosomal enzyme changes in diabetics arise by their leakage from damaged tissues (Waters et al., 1992). Recently it has been reported that only plasma N-acetyl-beta-Dglucosaminidase (B-NAG) but not cathep$\sin B$ activities showed higher values in type 2 diabetic patients (Piwowar et al., 2006). Moreover, type 1 diabetic patients showed significantly higher fraction $\beta$ form and lower A fraction form in total NAG (Jovanovic et al., 2008). The underlying cause of high plasma lysosomal enzyme concentrations is the increased lysosomal fragility and rupture due to increased lipid peroxidation of the lysosomal membrane (George, 2008). On the other hand, total NAG activities in NIDDM with or without complications were not changed considerably compared to the control group (Mandic and Filipovic, 1998).

Insulin is involved in the regulation of lysosomal biology (Duckworth et al., 1998; Granner, 2000). In this respect, insulin showed biphasic activities since in young rats, it suppressed lysosomal proteases activities while in old rats, insulin increased the activity of these lysosomal enzymes (Gromakova and Konovalenko, 2003). Lysosomal enzyme bioactivities are regulated in a glucose- independent way (Gromokova and Konovalenko, 2003).

Sulfonylureas and their analogues are currently a key in the pharmacological management of type 2 DM. Sulfonylureas are insulin secretagogues by which they mandate their anti hyperglycemic function that allows the achievement of their glucose metabolic targets (Tian et al., 1998; Scheen, 2005). Oral antidiabetic medications pose a significant morbidity and permanent sequelae and even mortality secondary to their accidental overdoses producing prolonged and severe hypoglycemia. However, prognosis is usually good if intervention using 50\% dextrose polus followed by $10 \%$ glucose infusion is initiated early (Spiller and Sawyer, 2006).

Few and mostly experimental works on antidiabetic overdose induced hypoglycemic effects on lysosomal enzyme activities has been reported (Gromokova and Konovalenko, 2003) and their results present obvious controversy.

Aim of this research was to determine the effect of accidental intake of insulin and/or sulfonylurea in overdoses on serum concentration of some lysosomal enzymatic activities [the carbohydrase; B-NAG; the protease : CATH-D, and the monophosphoric ester hydrolase NPAP] in patients with type 2 DM. 


\section{SUBJECTS and METHODS}

\section{(1) Hypoglycemic diabetic patient} group:

This group included 30 patients with type $2 \mathrm{DM}$. They were of medium build and age and free of chronic diabetic complications. These diabetic patients were receiving orally one of the sulfonylurea drugs (glibenclamide, gliclazide) and/or human insulin (the intermediate neutral protamine Hagedorn [NPH]) injection. All these patients were admitted to the Special Internal Medicine or the Emergency Hospitals of Mansoura University with severe hypoglycemia due to overdose injected insulin (8 patients), ingested sulfonylurea (10 cases) or both drugs (12 patients) beside missed meal intake, or severe stressful environment. Exclusion criteria were (i) Endocrinal disorders : pituitary, adrenal cortex, thyroid and/or gonadal dysfunctions. (ii) Smoking (more than 20 cigarettes/day) and (iii) Current treatment with drugs interfering with the antidiabetic therapy such as steroids.

(2) Euglycemic diabetic patients : 15 patients with controlled DM due to treatment by sulfonylurea, insulin or both together (4, 5 and 6 cases) beside diet control.

(3) Hyperglycemic diabetic patients : 15 patients with uncontrolled DM due to unsuccessful treatment by sulfonylurea, insu- lin or both together (6, 6 and 3 cases) beside diet control.

\section{(4) Healthy reference group:}

10 non diabetic healthy relatives of the investigated diabetic patients.

The members in the different groups were almost matched in sex, age and body weight (Table 1).

Before sampling, a frank consent was obtained directly from every patient or indirectly from a member of the patient's family after explaining the objectives of the study.

\section{Blood sampling:}

Eight $\mathrm{ml}$ venous blood were withdrawn from every patient in the different diabetic groups (1, 2 and 3) 3.0-4.0 hrs after the antihyperglycemic and breakfast intake as well as from the healthy reference individuals also after breakfast. From every sample $2.0 \mathrm{ml}$ blood were added into an EDTA containing tube to be used for plasma glucose, creatinine and bicarbonate determinations. The remaining blood was allowed to clot at room temperature and the serum was separated by centrifugation and stored at $-70^{\circ} \mathrm{C}$ till used for determination of the designated lysosomal enzymes within 2 months, a period that can be passed without loss of the aimed enzymes activities. 
Then, hypoglycemia was promptly and adequately corrected by intravenous glucose solution administration (starting by $50 \%$ dextrose polus followed by $10 \%$ infusion). On regaining clinical (neurological) and biochemical (plasma glucose) reliable good state, further oral carbohydrate diet and sugar drinks were taken to prevent relapse before patient discharge.

Immediately before being discharged due to clinical recovery, $5 \mathrm{ml}$ blood sample was withdrawn from every prehypoglycemic patient and serum was seperated and freezed till used for the designed lysosomal enzymes reassays.

\section{Methods:}

\section{Routine laboratory investigations for} plasma glucose and creatinine determinations (kits were obtained from Biomerieux-Vitek Inc. 595, Anglum Drive Hazelwood, Missouri 63042-2395 USA).

II. Plasma bicarbonate by AVL blood gas analyzer.

III Assay of some acidic lysosomal enzymes:

(1) Serum acid carbohydrase, N-acetyl B-glucosaminidase (B-NAG), [kits are supplied from Far Sn.I. via Enrico Fermi, 1237026 Settimo di Pescantis Verona, Italy] : At $\mathrm{pH} 4.0$ this enzyme catalyses the hydrolysis of p-nitro-phenil-Nacetyle B-D-glucosaminide to $\mathrm{N}$-acetyl glucosamine and p-nitrophenol. The liberated p-nitrophenol is proportionate to the enzyme B-NAG activity and is determined in alkaline medium. The intensity of the yellow product together with the corresponding blank sample and blank reagent are read colorimetrically at 400$420 \mathrm{~nm}$. The results are expressed in U/1 (Maruhn, 1976; Gressner and Roebruck, 1982; Pokrovsky et al., 1989).

\section{(2) Serum acid protease, cathepsin $D$} (CATH-D) : It is measured by incubating $0.5 \mathrm{ml}$ serum for three hours with denatured bovine hemoglobin $(50 \mathrm{mg} / \mathrm{ml})$ in $0.1 \mathrm{M}$ acetate buffer ( $\mathrm{pH}$ 3.6) and the reaction is terminated by adding $0.5 \mathrm{M}$ trichloracetic acid. Then, the tyrosine liberated by the protease activity is quantified by reading the blue colour produced by reaction of the serum- $\mathrm{Hb}$ mixture with Folin and Ciocalteu (1927) reagent in alkaline solution using a spectrophotometer at $660 \mathrm{~nm}$. CATH-D activities is expressed as ug tyrosine per $\mathrm{ml}$ serum per hour. The standard assay was achieved by preparing solution(s) of known tyrosine content (Gove et al., 1989).

\section{(3) Serum nonprostatic acid phospha-} tase: Serum total acid phosphatase originates from both prostatic and nonprostatic (almost within the lysosomes) sources while, prostatic acid phosphatase is inhibited by $\mathrm{L}(+)$ tartarate, the nonprostatic tartarate labile acid phosphatase is 
determined using 4-amino-antipyrine (King and Jegatheesan, 1959).

\section{Statistical analysis:}

All statistical calculations and graphic presentations of the data were performed by SPSS (Statistical Package for Social Science) version 11. Quantitative data were presented as mean $(\mathrm{X}) \pm$ standard deviation (SD). For comparing two sets of data, Mann-Whitney $\mu$ test was used to determine the significance of the difference between two groups. The linear relation between two variables was tested by Person correlation coefficient. Less than five percent probability $(\mathrm{P}<0.05)$ was adopted as the level of statistical significance

\section{RESULTS}

The results of this study are shown in Tables 1-4, Figures 1-3 and Diagram 1.

Table (1) shows the demographic data of the studied diabetic patients (hypoglycemics, euglycemics and hyperglycemics) on different antidiabetic therapies as well as in the healthy reference group. The investigated subjects are in general matched in age, sex and body mass index (BMI in $\mathrm{Kg} / \mathrm{m} 2$ ). However, some exceptions are found as the mean age $(\mathrm{p}<0.05)$ and BMI $(\mathrm{p}<0.01)$ in the hyperglycemic group when compared with their respectives in the healthy reference group.

Table (2) shows the levels of plasma glucose, creatinine and biocarbonate in type 2 diabetic patients (hypoglycemics, euglycemics or hyperglycemics) vesus the healthy reference group values. Plasma glucose levels $(\mathrm{mg} / \mathrm{dl})$ are significantly higher $(p<0.001)$ in the hyperglycemic group and significantly lower $(p<0.001)$ in the hypoglycemic group before plasma glucose correction in comparison to the corresponding values in euglycemic diabetic and reference groups. Also, plasma bicarbonate concentrations are significantly lower in the hypoglycemic patients before $(p<0.003)$ but not after $(p>0.05)$ regaining reliable glucose level in comparison to normal reference group data.

Table (3) shows the statistical data of serum lysosomal enzymes (B-NAG, CATH-D and NPAP) concentration in the studied diabetic patients (hypoglycemics, euglycemics and hyperglycemics) on different antidiabetic therapy (insulin, sulfonylurea or both together) as well as in the healthy reference group. Serum NPAP (in king-Armstrong units/dl), B-NAG (U/L) and CATH-D (ug tyrosine $/ \mathrm{ml} / \mathrm{hr}$ ) levels increased in diabetic patients with drug induced hypoglycemia $(1.8 \pm 0.4$, $10.9 \pm 3.0,20.7 \pm 5.1$ respectively) or with uncontrolled DM and hyperglycemia (1.1 $\pm 0.3,8.1 \pm 2.9,17.8 \pm 3.7$ respectively) than those with controlled DM and euglycemia $(0.96 \pm 0.33,5.0 \pm 1.8,14.4 \pm 2.2$ respectively) or healthy reference $(0.8 \pm 0.25,3.8 \pm$ $1.1,13.5 \pm 1.4$ respectively) groups but no 
significant difference in such lysosmal enzyme activities between the hypoglycemic diabetics before $(1.8 \pm 0.4,10.9 \pm 3.0$, $20.7 \pm 5.1$ respectively) and after $(1.5 \pm 0.4$, $9.4 \pm 2.8,16.8 \pm 3.5$ respectively) management and the uncontrolled hyperglycemic diabetics $\quad(1.1 \pm 0.3,8.1 \pm 2.9,17.8 \pm 3.7$ respectively) (Table 3 ). The well controlled diabetics had significantly lower mean activity of serum lysosmal enzymes than the poorly controlled diabetics.

Figures (1, 2 and 3) : These Figures illusterate the serum concentration states of the different studied lysosomal enzymes before and after receiving the respective antihyperglycemic therapy (insulin, sulfonylurea and both drugs together). The figures show that insulin overdose induces the highest increase in libation of the studied lysosomal enzymes non-prostatic acid phosphatase (NPAP), BN-acetyle glucosamindase (B-NAG) and cathepsin-D (CATH-D) and consequently their serum concentrations. The strength of enzyme activity response to insulin is followed by both insulin and sulfonylurea intake together and lastly that of sulfonylurea. However, the drug additive effect is not complete.

Diagram (1): Positive correlation between various variables in different diabetic groups. Significantly positive correlations between the different lysosomal enzyme activities were observed in diabetic patients. However, no correlation was shown between any of the studied enzymes and plasma glucose concentrations in the different groups.

\section{DISCUSSION}

Although acidic lysosomal enzymes are originally found as intracellular organelles in most tissues, small amounts of them leake to the plasma. The major factor responsible for changes in plasma levels of the acidic lysosomal hydrolases was injury of tissues rich in such enzymes. Beside their biological function within the cells, these enzymes may break down the endothelial membrane glycoconjugates. Due to variability among these enzyme bioactivities, more than one enzyme should be assayed in any protocol (Gasting et al., 2006).

In management of type $2 \mathrm{DM}$, oral antihyperglycemic should be tried before insulin therapy is allowed (Scheen, 2005). Antihyperglycemic therapy prevents or reduces morbidity and mortality caused by the relatively common serious diabetic complications (Riley and Kastrup, 2001). However, hypoglycemia may occur if more than really required antihyperglycemic therapy is taken, there is a missed meal after intake of the recommended therapy and / or development of unplanned physical or mental stress (Granner, 2000). 
In the present study, accidental intake of insulin and/or oral antihyper-glycemic drug(s) in overdoses induced significant increase of the estimated serum lysosomal enzymes most probably due to the induced intracellular hypoglycemia. In this respect, the reaction to insulin was higher but shorter than sulfonylurea. At the same time, B-NAG had higher response than CATH-D and NPAP to the same antihyperglycemic drug overdoses (Table 3 and Figures 1-3). Any lysosomal enzyme may be changed independent of others reflecting the pathological rather than the pharmacological action of the inducing agent. The enhanced release of the lysosomal hydrolases may be due to increased lysosomal membrane permeiability or even its degeneration. Subsequently, antihyperglycemic drug overdoses and/or the resulting induced intracellular hypoglycemia exerted a marked labilizing effect on B-NAG. The stabilizing or labilizing effect of a compound on lysosomal membrane depends highly on its dosage and exposure time (Rupar et at., 1992; Geetra, 1993). Therefore, antihyperglycemic drug(s) through their metabolic actions were involved in regulation of lysosomes biology. On the other hand, there was no significant correlation between plasma glucose concentrations and different serum lysosomal enzyme activities (Diagram 1). Discharge of patients from the hospital was encouraged only after plasma glucose levels were maintained within the reference range for at least one hour (Table 2). At this time, the determined enzymes were still significantly higher than their respectives in normal controls (Table 3). This may be due to their prolonged half life simulating other plasma glycoproteins.

The results of the present study (Table 3) contradicit some experimental data. So, histochemical studies of the aortas of diabetic animals on insulin administration showed marked reduction in the activities of NPAP and B-NAG lysosomal enzymes (Wolinsky et al., 1998). In addition, Solomon and Colleagues (2000) found that insulin administration suppressed the activities of lysosomal cathepsins in rats. However, insulin injection into old animals paradoxically increased the activity of lysosomal enzymes in plasma (Gromakova and Konovalenko, 2003). Moreover in man, total NAG activities in patients with NIDDM with or without complications did not change considerably compared to the control group (Mandic and Filipovic, 1998). In turn, insulin and subsequently its secretagogues are involved in the regulation of lysosomal enzymes synthesis, secretion and/or release (Duckworth et al., 1998; Granner, 2000). The present study showed that plasma glucose levels were not correlated with serum lysosmal enzyme concentrations (Table 4). This finding confirms the belief that lysosomal enzymes production is a plasma glucose-independent process (Gromokova 
and Konovalenko, 2003).

In the present study (Table 3), the different serum lysosomal enzyme concentrations were significantly higher in the uncontrolled hyperglycemic patients than their corresponding values in the healthy reference group. However, they were significantly lower than their respective levels in the hypoglycemic patient group before resuscitation. Lysosomal enzymes were not completely dependent on plasma glucose level. This may be due to exhaustion of the lysosome organelles by disease chronicity. The levels of the different serum lysosomal enzymes in the controlled euglycemic patients showed no significant difference in comparison to their corresponding healthy reference group values but significantly lower than their respectives in the hypoglycemic patient group.

Numerous articles have handled this subject. Diabetic patients had higher concentrations of blood lysosomal enzymes e.g., NB-acetyl glucosaminidase (B-NAG) than the control subjects (Agardh et al., 1991). Recently it has been reported that only plasma N-acetyl-beta-Dglucosaminidase (B-NAG) but not cathep$\sin B$ activities showed higher values in type 2 diabetic patients (Piwowar et al., 2006). Moreover, type 1 diabetic patients showed significantly higher fraction $B$ form and lower A fraction form in total B-
NAG content compared with the control (Jovanovic et al., 2008). The underlying cause of the increased B-ANG plasma levels may be lysosomal fragility due to increased lipid peroxidation of the lysosomal membrane (George, 2008) inducing enzyme leakage from the damaged cells or tissues. This can explain the finding that all lysosomal enzyme activities are increased, the magnitude of which are related to the respective lysosomal enzyme content.

Further, during short-term hypoglycemic conditions $(<4.0$ hour) induced by exogenous antihyperglycemic overdose, the activities of the objective lysosomal enzymes were increased (Table 3). After successful management of the hypoglycemia by parenteral glucose injection, partial but not complete correction of serum lysosomal enzyme anomalies was noted. Although hypoglycemia was corrected and clinical and routine laboratory (plasma glucose and biocarbonates) testing were regained (Table 2), serum lysosmal enzymes were still significantly higher than healthy reference and controlled diabetic groups (Table 3 and Figures 1-3).

Alternatively, the involvement of some pancreatic islet acidic lysosomal enzymes in insulin secretory process is not yet settled. In response to glucose induced insulin release, the pancreatic islet activities for N-B-acetyl- D-glucosaminidase, 
cathepsin D and acid phosphatase were reduced in diabetic rats compared with the control. However, normalization of glycemia in these rats by phlorizin did not influence the lysosomal enzyme activities (Salehi et al., 1999). On the other hand, direct glucose infusion did not affect the islets activities of acid phosphatase and Nacetylbeta-D-glucosaminidase (Lundquist and Panagiotidis, 1992).

\section{Acknowledgement:}

Our sincere thanks and atmost appreciation to Dr. Ghada M.H.El-Kannishy, Assistant Professor of Internal Medicine, Faculty of Medicine, Mansoura University for her objective help and scientific advise in this article. 
Table (1): Demographic data of the studied diabetic groups (hypoglycemics, euglycemics and hyperglycemics) as well as in the healthy reference group.

\begin{tabular}{|c|c|c|c|c|}
\hline \multirow{2}{*}{ Data } & \multirow{2}{*}{$\begin{array}{l}\text { Age in } \\
\text { Years }\end{array}$} & \multicolumn{2}{|c|}{ Sex } & \multirow{2}{*}{$\begin{array}{c}\text { BMI } \\
\mathrm{Kg} / \mathrm{m}^{2}\end{array}$} \\
\hline & & females & males & \\
\hline Healthy reference group (10 cases) & $46.9 \pm 3.5$ & 5 & 5 & $23.8 \pm 1.2$ \\
\hline Hypoglycemic group (30 cases) & $48.6 \pm 5.5$ & 17 & 13 & $24.4 \pm 1.2$ \\
\hline Euglycemic group (15 cases) & $48.7 \pm 4.1$ & 8 & 7 & $25.0 \pm 1.4$ \\
\hline Hyperglycemic group (15 cases) & $51.2 \pm 4.4^{*}$ & 9 & 6 & $27.1 \pm 2.0$ \\
\hline
\end{tabular}

P1 $(>0.05) \quad$ No significant difference between healthy vs hypoglycemic.

P2 $(<0.01) \quad$ Significant difference between healthy vs hyperglycemics.

P3 $(<0.05) \quad$ Significant difference between hypoglycemics vs hyperglycemics.

P4 $(<0.05) \quad$ Significant difference between hypoglycemics vs hypoglycemics.

P5 $(>0.05) \quad$ No significant difference between euglycemics vs euglycemics.

P6 (>0.05) No significant difference between hyperglycemics vs euglycemics.

Table (2): Plasma glucose, creatinine and bicarbonate concentration in type 2 diabetic patients (hypoglycemics, euglycemics or hyperglycemics) versus the healthy reference group values.

\begin{tabular}{|c|c|c|c|c|}
\hline \multicolumn{2}{|l|}{ Data } & $\begin{array}{c}\text { Plasma } \\
\text { glucose } \mathbf{m g} / \mathrm{dl}\end{array}$ & $\begin{array}{c}\text { Plasma creatinine } \\
\mathrm{mg} / \mathrm{dl}\end{array}$ & $\begin{array}{c}\text { Plasma } \\
\text { bicarbonate } \\
\text { mmol/l }\end{array}$ \\
\hline \multicolumn{2}{|l|}{ Healthy reference group (10 cases) } & $95.3 \pm 6.8$ & $0.91 \pm 0.2$ & $28.3 \pm 6.5$ \\
\hline \multirow{2}{*}{ Hypoglycemic group (30 cases) } & Before & $48.1 \pm 5.1$ & $0.94 \pm 0.28$ & $20.1 \pm 5.8$ \\
\hline & After & $117.3 \pm 3.9$ & $0.88 \pm 0.19$ & $22.4 \pm 3.3$ \\
\hline \multicolumn{2}{|l|}{ Euglycemic group (15 cases) } & $120.8 \pm 11.7$ & $1.1 \pm 0.2$ & $27.0 \pm 5.0$ \\
\hline \multicolumn{2}{|l|}{ Hyperglycemic group (15 cases) } & $279.6 \pm 23.5$ & $1.3 \pm 0.27$ & $26.3 \pm 6.4$ \\
\hline \multirow{2}{*}{$\begin{array}{l}\text { P1 Significant difference between } \\
\text { healthy vs hypoglycemic. }\end{array}$} & Before & $<0.0001$ & $>0.05$ & $<0.001$ \\
\hline & After & $<0.0001$ & $>0.05$ & $<0.01$ \\
\hline \multicolumn{2}{|l|}{$\begin{array}{l}\text { P2 Significant difference between } \\
\text { healthy vs hyperglycemics }\end{array}$} & $<0.0001$ & 0.001 & $>0.05$ \\
\hline \multicolumn{2}{|l|}{$\begin{array}{l}\text { P3 Significant difference between } \\
\text { healthy vs euglycemics }\end{array}$} & $<0.0001$ & 0.05 & $>0.05$ \\
\hline \multicolumn{2}{|l|}{$\begin{array}{l}\text { P4 Significant difference between } \\
\text { hypoglycemics vs hyperglycemics }\end{array}$} & $<0.0001$ & $<0.001$ & $<0.0001$ \\
\hline \multicolumn{2}{|l|}{$\begin{array}{l}\text { P5 Significant difference between } \\
\text { hypoglycemics vs euglycemics }\end{array}$} & $<0.0001$ & $<0.01$ & $<0.001$ \\
\hline \multicolumn{2}{|l|}{$\begin{array}{l}\text { P6 Significant difference between } \\
\text { hyperglycemics vs euglycemics }\end{array}$} & $<0.0001$ & $<0.01$ & $>0.05$ \\
\hline
\end{tabular}


Table (3): Statistical data of serum lysosomal enzymes of the studied diabetic patients (hypoglycemics, euglycemics and hyperglycemics) on different antidiabetic therapy as well as in the healthy reference group.

\begin{tabular}{|c|c|c|c|c|}
\hline \multicolumn{2}{|l|}{ Data } & $\begin{array}{c}\text { Non } \\
\text { Prostatic acid } \\
\text { phosphatase } \\
\text { (KAU/dl) }\end{array}$ & $\begin{array}{c}\text { Acidic } \\
\text { cathepsin-D } \\
\text { (ug tyrosine } / \mathbf{m l} / \mathbf{h r} \text { ) }\end{array}$ & $\begin{array}{c}\text { N-B-acetyl-D } \\
\text { gluosamindase } \\
(\mathrm{U} / \mathrm{L})\end{array}$ \\
\hline \multicolumn{2}{|l|}{ Healthy reference group (10 cases) } & $0.8 \pm 0.25$ & $3.8 \pm 1.1$ & $13.5 \pm 1.4$ \\
\hline \multirow{2}{*}{ Hypoglycemic group (30 cases) } & Before & $1.8 \pm 0.4$ & $10.9 \pm 3.0$ & $20.7 \pm 5.1$ \\
\hline & After & $1.5 \pm 0.4$ & $9.4 \pm 2.8$ & $16.8 \pm 3.5$ \\
\hline \multicolumn{2}{|l|}{ Euglycemic group ( 15 cases) } & $0.96 \pm 0.33$ & $5.0 \pm 1.8$ & $14.4 \pm 2.2$ \\
\hline \multicolumn{2}{|l|}{ Hyperglycemic group (15 cases) } & $1.1 \pm 0.30$ & $8.1 \pm 2.9$ & $17.8 \pm 3.7$ \\
\hline \multirow{2}{*}{$\begin{array}{l}\text { P1 Significant different between } \\
\text { healthy vs hypoglycemic }\end{array}$} & Before & $<0.0001$ & $<0.0001$ & $<0.0001$ \\
\hline & After & $<0.0001$ & $<0.0001$ & $<0.0001$ \\
\hline \multicolumn{2}{|l|}{$\begin{array}{l}\text { P2 Significant different } \\
\text { between healthy vs hyperglycemics }\end{array}$} & $<0.0001$ & $<0.0001$ & $<0.0001$ \\
\hline \multicolumn{2}{|l|}{$\begin{array}{l}\text { P3 Significant different } \\
\text { between healthy vs euglycemics }\end{array}$} & $>0.05$ & $<0.05$ & $>0.05$ \\
\hline \multicolumn{2}{|l|}{$\begin{array}{l}\text { P4 Significant different } \\
\text { between hypoglycemics vs hyperglycemics }\end{array}$} & $<0.0001$ & $<0.0001$ & $<0.01$ \\
\hline \multicolumn{2}{|l|}{$\begin{array}{l}\text { P5 Significant different between } \\
\text { hypoglycemics vs euglycemics }\end{array}$} & $<0.0001$ & $<0.0001$ & $<0.0001$ \\
\hline \multicolumn{2}{|l|}{$\begin{array}{l}\text { P6 Significant different between } \\
\text { hyperglycemics vs euglycemics }\end{array}$} & $>0.05$ & $<0.05$ & $<0.0001$ \\
\hline
\end{tabular}

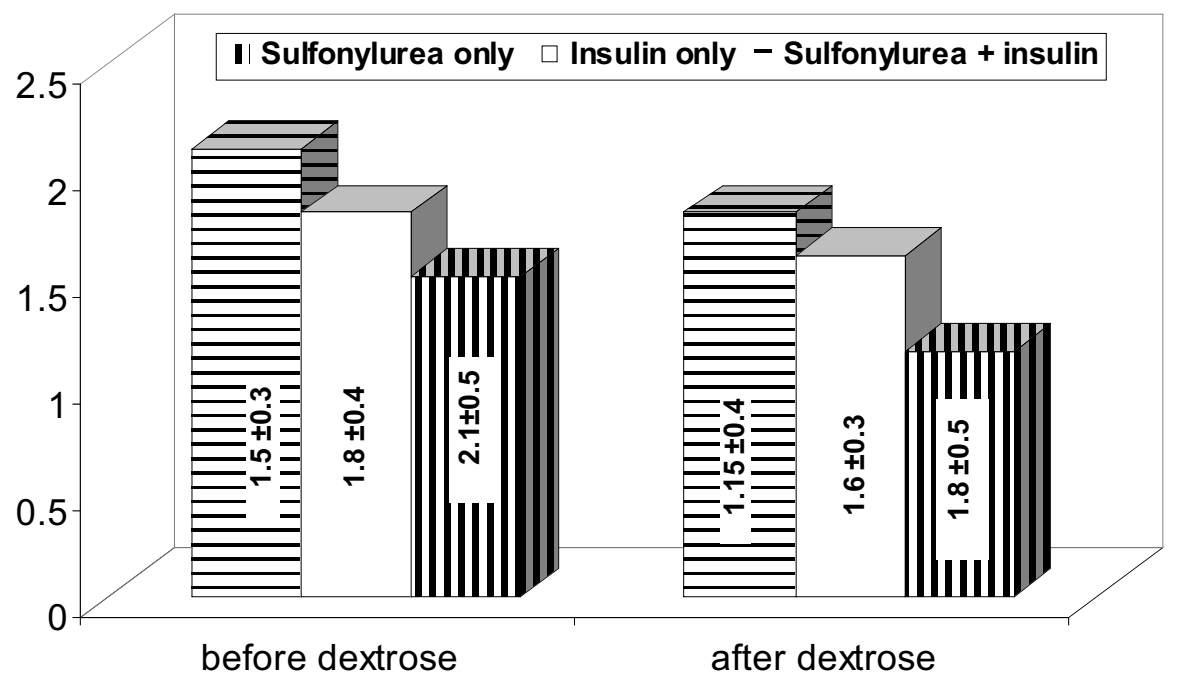

Figure (1): Serum NPAP concentration in patients with accidentally antidiabetic drug induced hypoglycemia before and after its correction. 


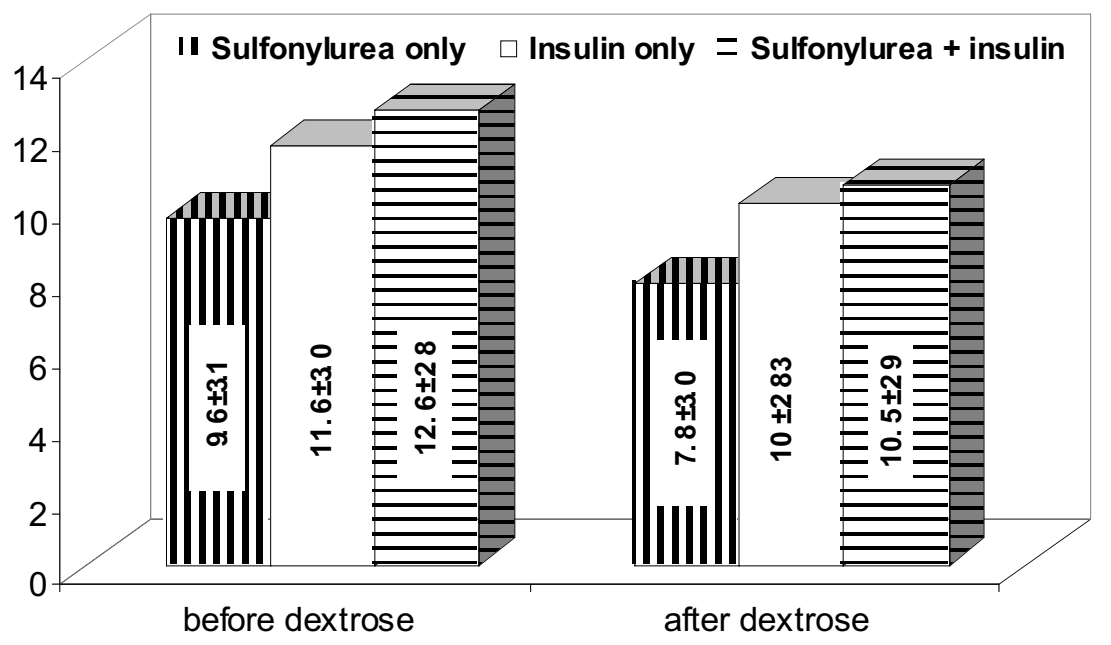

Figure (2): Serum B-NAG concentration in patients with accidentally antidiabetic drug induced hypoglycemia before and after its correction.

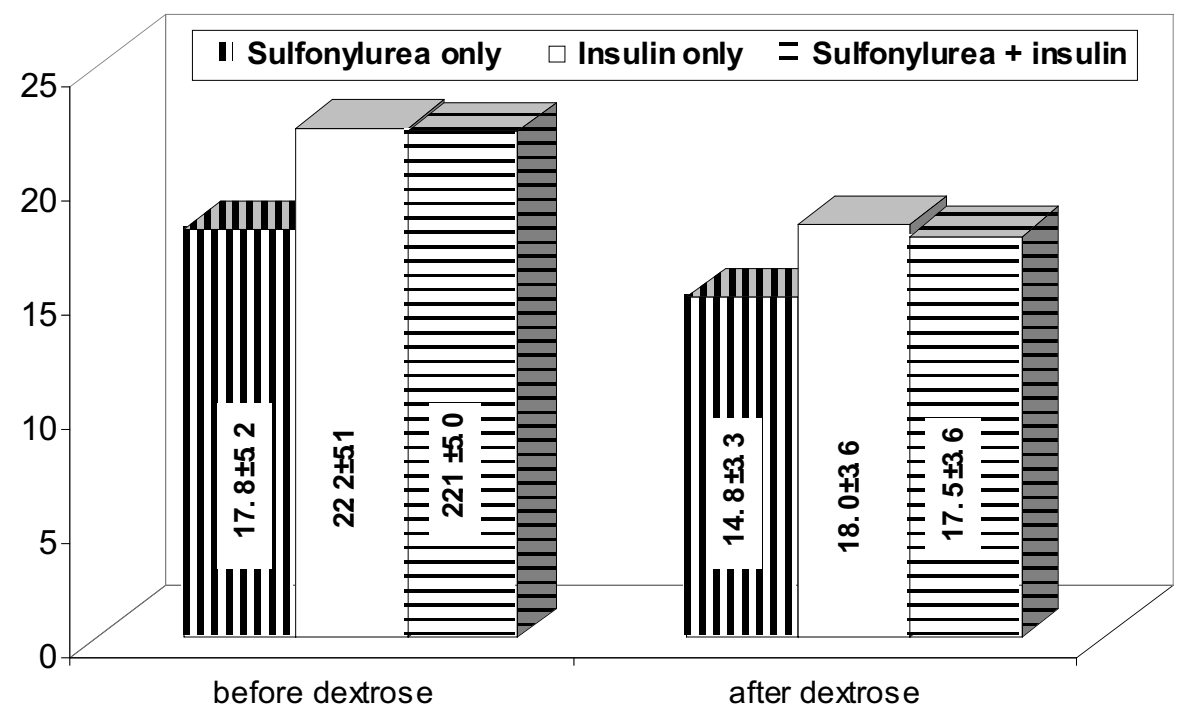

Figure (3): Serum CATH-D concentration in patients with accidentally antidiabetic drug induced hypoglycemia before and after correction. 


\begin{tabular}{|c|c|c|c|c|c|c|}
\hline Data & NPAP & B-NAG & CATHD & NPAP & B-NAG & CATH-D \\
\hline Glucose & $\begin{array}{lll}\text { N1 } & \\
& \\
& \text { N3 }\end{array}$ & $\begin{array}{ll}\text { N1 } & \\
& \\
& \text { N3 }\end{array}$ & N3 & $\begin{array}{lll}\mathrm{N} 2 & \\
& \mathrm{~N} 4\end{array}$ & $\begin{array}{lll}\mathrm{N} 2 & \\
& \mathrm{~N} 4\end{array}$ & N4 \\
\hline NPAP & & $\begin{array}{ll}\text { S1 } & \\
& \text { S3 }\end{array}$ & $\begin{array}{lll}\text { S1 } & \\
& \text { S3 }\end{array}$ & & \begin{tabular}{|ll} 
S2 & \\
& \\
& S4 \\
\end{tabular} & I I \\
\hline B-NAG & $\begin{array}{lll}\text { N1 } & \\
& \\
& \text { N3 }\end{array}$ & & S3 & $\begin{array}{ll}\mathrm{N} 2 & \\
& \mathrm{~N} 4\end{array}$ & & S4 I \\
\hline CATH-D & $\begin{array}{lll}\text { N1 } & \\
& \\
& \text { N3 }\end{array}$ & S3 & & $\begin{array}{lll}\mathrm{N} 2 & \\
& \mathrm{~N} 4\end{array}$ & $\begin{array}{lll}\text { S2 } & \\
& \text { S4 }\end{array}$ & 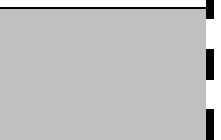 \\
\hline
\end{tabular}

Diagram (1): Positive correlation between different variables in healthy reference, (1) hypoglycemic (2), euglycemics (3) and hyperglycemic (4) diabetic patients.

$\mathrm{N}$ : Non-significant $(\mathrm{P}>0.5)$ difference.

$\mathrm{S}$ : Significant $(\mathrm{P}<0.05)$ difference. 


\section{REFERENCES}

Agardh, C. D.; Agardh, E.; Issakson, E. and Hultberg, B. (1991) : "Association between urinary $\mathrm{N}$-acetyl-beta-glucosamindase and its isoenzyme patterns and microangiopathy in type 1 diabetes mellitus". Clin Chem., 37: 1696-1699.

Duckworth, W. C.; Bennett, R. A. and Hamel, F. G. (1998) : Endocrine Rev., 19 : 608-624.

Folin, O. and Coicalteu, V. (1927) : J. Biol. Chem., 73: 627.

Gatsing, D.; Garba, I. and Adoga, G. (2006): "The use of lysosomal enzymuria in the early detection and monitoring of the progression of diabetic nephropathy". Indian J. Clin. Biochem., 21(2):42-48.

Geetra, A. (1993) : "Effect of alpha Tocopherol on Oxorubicin-induced changes in rat heart lysosomal Enzymes". Indian J. Exp. Biol., 31 (3): 288-290.

George, J. (2008) : "Elevated serum beta glucuronidase reflects hepatic lysosomal fragility following toxic liver injury in rats". Biochem. Cell Biol., 86 (3): 235-243.

Gove, C. D.; Wardle, E. N. and Williams R. (1989) : "Circulating lysosomal enzymes and acute hepatic necrosis". J. Clin. Pathol., 34: 13-16.
Granner, D. K. (2000) : Insulin. In: Harper's Biochemisty. 25th edition, Murray, R. K.; Granner, D. K.; Mayes, P. A. (Eds.), Rowell VW, P.P. 611-626.

Gressner, A. M. and Roebruck P. (1982) : Clin. Chem. Acta., 124: 315.

Gromakova, L. A. and Konovalenko (2003) : "Lysosomal proteolysis: Effects of aging and insulin". Biochemistry (Moseow), 68 (7): 772-775.

Jovanovic, V. B.; DimitrijevicSreekovic, V. S. and Mandic, L. M. (2008) : "Serum N-acetyl-beta-D-gluosamindase profiles in type I diabetes secondary complications: cause of changes and significance of determination". J. Clin. Lab. Anal., 22 (4): 307-313.

Junqueira, L; Carnerio, J. and Hill, M. (2005) : “The cytoplasm". Basic Histology Text and Atlas. 11: 36-39.

King, E. J. and Jagatheesan, K. A. (1959) : J. Clin. Path., 12: 85.

Lundquist, I. and Panagiotidis, G. (1992) : "The relationship of islet amyloglucosidase activity and glucose-induced insulin secretion". Pancreas., 7: 352-357.

Maehr, R.; Mintern, J.; Herman, A.; Lennon-Durnenil, A.; Mathis D. and Benoist C. (2005) : "Cathepsin L is 
essential for onset of autoimmune diabetes in NOD mice". J. Clin. Invest., 115 (10): 2934-2943.

Mandic, L. and Filipovic, D. (1998) : "Changes of isoenzymes of serum $\mathrm{N}$ acetyl-beta -D-glucosaminidase in relation of different types of diabetes". Biochem. Mol. Biol. Int., 45 (3): 545-554.

Maruhun, D. (1976) : Clin. Chem. Acta, 73: 453.

Megarbane, B.; Deye, N.; Bloch, V.; Sonneville, R.; Collet, C.; Launay, J. M. and Boud, F. J. (2007) : “Interntional overdose with insulin: Prognostic factors and toxicokinetic / toxicodynamic profiles". Gut Care., 11 (5): R115.

Piwowar, A.; Knapik-Kordecka, M.; Fus, I. and Warwas, M. (2006) : “Urinary activities of cathepsin B; N-acetyl-beta-Dglucosaminidase; and albuminuria in patients with type 2 diabetes mellitus". Med. Sci. Monit., 12 (5): 210-214.

Pokrovsky, A.; Archakov, A. T.; Lyubimtseva, O. N.; Strove, E. A. and Makarova, V. O. (1989) : Laboratory Manual In Biochemistry.

Riley, M. R. and Kastrup, E. R. (2001) : Insulin. In : Drug Facts and Comparison. The $5^{\text {th }}$ edition, St. Louis, Missouri, USA, P.P. 294-296.
Rupar, C. A.; Albo, S. and Whitehall, J. D. (1992) : "Rat liver lysosomal membranes are enriched in alpha Tocopherol". Biochem. Cell. Biol., 70 (6): 486-488.

Salehi, A.; Henningsson, R.; Mosen, H.; Ostenson, C.; Efendic, S. and Lundquist, I. (1999) : "Dysfunction of the islet lysosomal system conveys impairment of glucose-induced insulin release in the diabetic GK Rat". Endocrinology, 140 (7): 3045-3053.

Scheen, A. J. (2005) : “Drug interaction of clinical importance with antihyperglycemic agents : an update". Drug Saf., 28 (7): 601-631.

Solomon, V.; Madihally, S.; Yarmush M. and Toner, M. (2000) : "Insulin suppression of the increased activities of lysosomal cathepsins and ubiquity conjugation system in burn-injury rats". J. Surg. Res., 93 (1): 120-126.

Spiller, H. A. and Sawyer, T. S. (2006) : "Toxicology of oral antidiabetic medications". Am. J. Health Syst. Pharm., 63 (10): 929-938.

Tian, Y. A.; Johnson, G. and Ashcroft, S. J. (1998) : "Sulfonylureas enhance exocytosis from pancrearic beta cells by a mechanism that does not involve direct activation of protein kinase $C^{\prime \prime}$. Diabetes, 47 (11): 1722-1726. 
van Meel, E. and Klumperman, J. tionship to diabetic complications and (2008) : "Imaging and imagination : glycacmic control". Dialectologics, 35 (10): understanding the endo-lysosomal sys- 991-995.

tem". Histochem. Cell Biol., 129 (3): 253266.

Wolinsky, H.; Goldfisher, S.; Capron, L.; Capron, F.; Coctoff-Schiller, B. and Waters, P. J.; Flynn, M. D.; Corall, R. J. Kasak, L. (1998) : “Hydrolase activities in and Pennock, C. A. (1992) : "Increase in the rat aorta: effects of diabetes mellitus plasma lysosomal enzymes in type 1 (in- and insulin treatment". Enzyme, 33 (3): sulin dependent) diabetes mellitus rela- 155-165. 


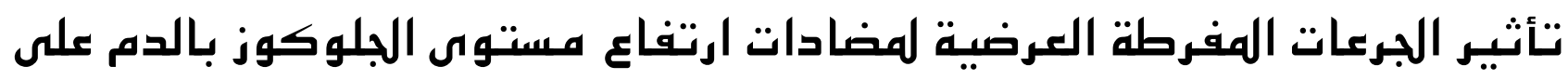

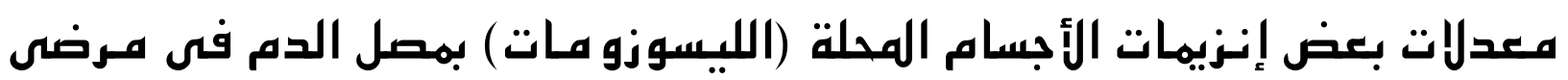 البول السكرى مـ النوع الثانى} المشتركون فى البحث

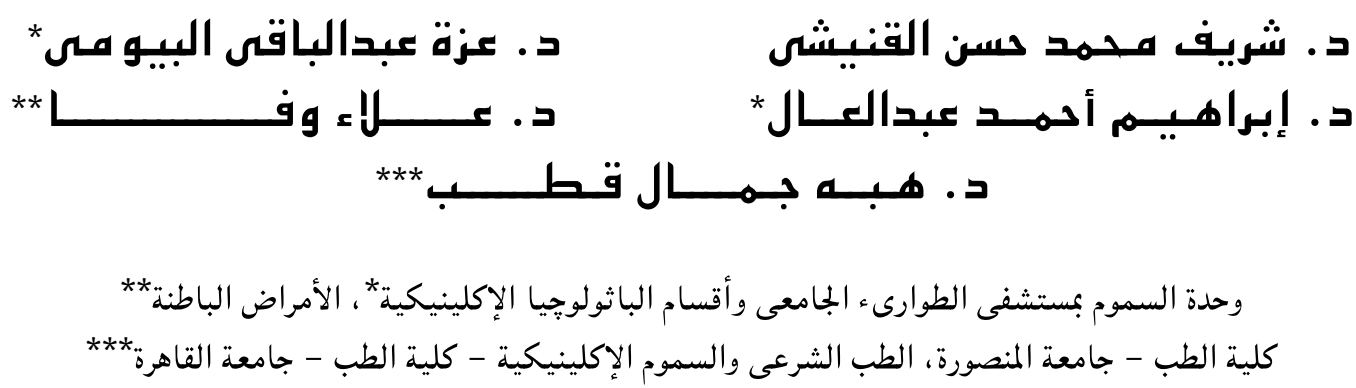

الأجسام المحلة أى الليسوزومات عبارة عن ظروف بداخلها إنزيمات حمضية النشاط وهى موجودة فى سيتوبلازم الخلايا وعادة ماتتسرب هذه

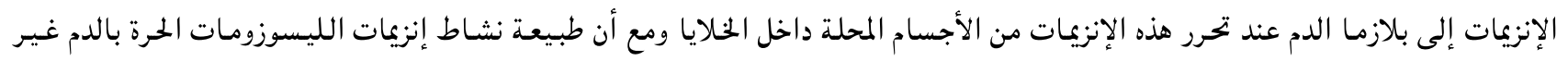

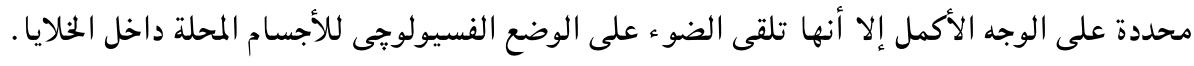
إن مرض السكر البولى هو من الأمراض المؤثرة على أيض الخلية وبالتالى على الليسوزومات بها ويعتبر تقييم تأثر الأجسام المحلة بزيادة

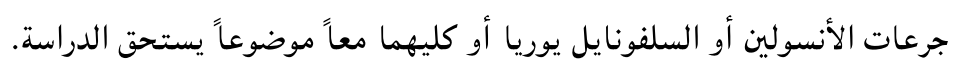
من هذا البحث دراسة تأثر معدلات نشاط بعض الإنزيمات المحلة بصل الدم فى مرضى البول السكرى المصابون بهبوط حاد فى معدل الجلوكوز بالدم نتيجة تعاطى جرعات زائدة عن المقرر من الأنسولين أو السلفونيل يوريا.

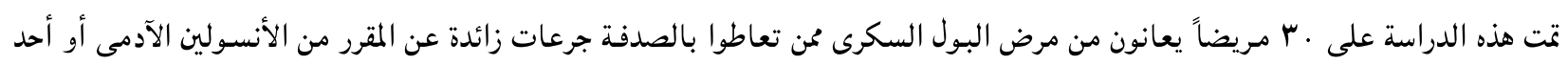

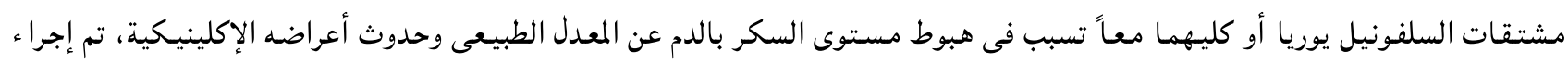

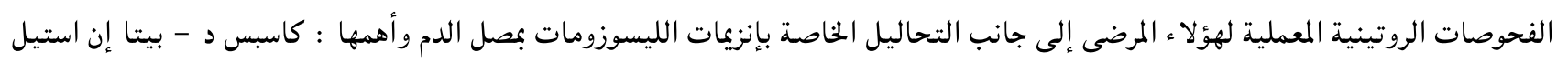
جلوكوز أمينيديز وإنزيم الفوسفاتيز الحمضى. لقد أوضحت الدراسة أن تعاطى الأنسولين أو مركبات السلفونيل يوريا عرضياً بجرعات أكثر مما هو مقرر علاجياً لمرضى السكر البولى قد

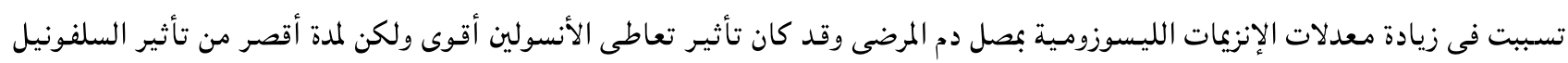

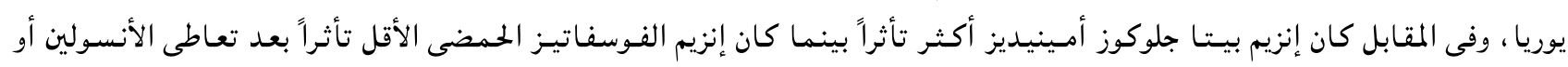
السلفونيل يوريا بكميات زائدة.

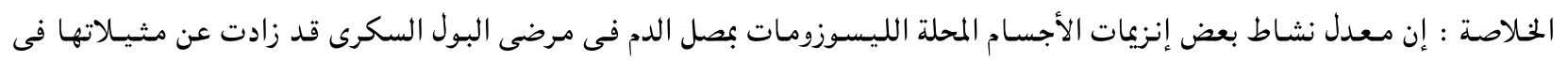

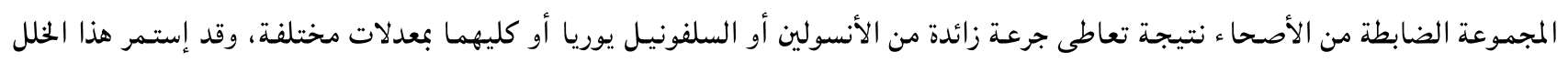
لفترة بعد تصحيح معدل الجلوكوز بالدم. 